\title{
The antioxidant and antibacterial activities of the essential oils of Marrubium vulgare growing wild in Eastern Algeria
}

\author{
Abderazak Abadi, Fahima Abdellatif * \\ Laboratoire de Molécules Bio-active et Valorisation de la Biomasse, École Normale Supérieure, \\ BP 92, Kouba - Algiers, Algeria \\ *E-mail address: ryadabadi@gmail.com
}

\begin{abstract}
The chemical composition was analyzed by gas chromatography (GC) and gas chromatography/mass spectrometry (GC/MS). The constituents were identified by their mass spectra and Kovats' indices. Fivety (50) components in the oil of $M$. vulgare were identified. The results demonstrated that the major components of the essential oil were : 4,8,12,16-Tetramethyl heptadecan4-olid (16.97 \%), Germacrene D-4-ol (9.61 \%), $\alpha$ - pinéne (9.37 \%), Phytol (4.87\%), Dehydro-sabina ketone (4.12\%), Piperitone (3.27\%), $\delta$-Cadinene (3.13\%), 1-Octen-3-ol (2.35\%) and Benzaldehyde $(2.31 \%)$. The antioxidant activity of the oils was assessed by measurement of metal chelating activity, the reductive potential, the free radical scavenging (DPPH) assay. The antioxidant activity was compared with that of synthetic antioxidants: butylated hydroxyanisole (BHT), and the essential oils . The results showed as the Essential oil of $M$ vulgare was evaluated for its antibacterial activities against Gram-positive and Gram negative pathogenic bacteria: Listeria monocytogene, Pseudomonas aeruginosa, Agrobacterium tumefaciens and Salmonella enterica.
\end{abstract}

Keywords: Marrubium vulgare; Essential oil composition; GC/MS; antibacterial activities; antioxidant

\section{INTRODUCTION}

The chemical compositions of M. vulgare essential oil from various origins have been the subject of many studies. The literature reveals the occurence of several chemotypes. From Lithuania, (Z)-b-farnesene, b-caryophyllene, (E)-2-hexenal, a-humulene and germacrene D were the main components of M. vulgare essential oil [1]. From Czech Republic, the main constituents of M. vulgare essential oil were b-caryophyllene and germacrene D [2]. From different region of Iran, the main constituants of $\mathrm{M}$. vulgare essential tricyclene, b-pinene, bisabolol, b-elemone and isomenthon-8-thiol [3], b-bisabolene, 8-cadinene and isocaryophyllene [4], and bisabolene, b-caryophyllene, germacrene D and E-bfarnesene [5], caryophyllene oxide, b-caryophyllene and germacrene D [6].

Nowadays, the interest in naturally occurring antioxidants has considerably increased for use in food, cosmetic and pharmaceutical products to replace synthetic antioxidants which are being restricted due to their carcinogenicity [7,8]. Aromatic and medicinal plants are the source of natural antioxidants thanks to their main secondary metabolites such as polyphenols 
and essential oils. Phenolic compounds are biochemically synthesized via the shikimate pathway, which produces the group of phenolics called phenylpropanoids [9].

They can act as antioxidants by donating hydrogen to highly reactive radicals, thereby preventing further radical formation [10]. Essential oils also called volatile or ethereal oils are aromatic oily liquids obtained from different plant parts and widely used as food flavours [11]. Essential oils are complex mixers comprising many single compounds. Synthetic antioxidants are widely used to retard undesirable changes as a result of oxidation in many foods. Excessively, oxidized fats and oils are not suitable for nutritive purposes. Because the oxidation products of oils have toxic effects, many synthetic substances such as propylgallate and citric acid are commonly used in lipids to prevent oxidation. Recently, these synthetic substances have been shown to cause effects, such as enlarging the liver size and increasing the microsomal enzyme activity. The use of butylated hydroxyanisole (BHA), butlylated hydroxytoluene (BHT) and $\alpha$-tocophérol have been restricted in food because of its carcinogenic effect. Therefore, the search for new natural antioxidant sources has been greatly intensified. In this field, plant originated antioxidants have been widely used in oils or lipid containing foods in order to prevent oxidative deterioration. The main purpose of this study was to investigate the chemical composition of $M$. vulgare essential oil and to determine its antioxidant activity by Scavenging of DPPH (1,1- diphenyl-2-picrylhydrazyl) test. The plant is reported to possess hypoglycemic [12], vasorelaxant [13], antihypertensive [14], analgesic $[15,16]$, anti-inflammatory [17], antioxidant activity [1,18], antiedematogenic activity [19], and many other biological activities. In Algeria folk medicine, it was used as hypotensive, hypoglycemic and cardiotonic. Recently, a large number of essential (volatile) oils and their constituents have been investigated for their biological activity, notably antibacterial and antioxidant properties [20-21]. Essential oils and their components are gaining increasing interest as a natural alternative to synthetic drugs [22], particularly against microbial agents because of their relatively safe status wide acceptance by consumers and their exploitation for potential multipurpose functional use.

The interest in plants with antibacterial properties has been revived because of current problems associated with the use of antibiotics [23]. Therefore, essential oils and other naturally occurring antibacterial are attractive to the food industry as well as imparting flavor [24]. More recently, the essential oil of this plant was advocated for their use as an antioxidant agent [18], but to the best of our knowledge, there are no reports on the antimicrobial properties and the cytotoxicity has been published. Therefore, this paper was conducted to investigate for the first time the antibacterial properties against clinical and pathogenic microorganisms and the cytotoxicity of M. vulgare essential oil grown in Algeria.

\section{MATERIALS AND METHODS}

\section{1. Plant material}

Plant materials (aerial parts) of $M$. vulgare L. were grown in the zone of Nigrine district of El-Ater in the wilaya of Tebessa, north east of Algeria. The whole plants were collected during the period of May to June 2009.

\section{2. Distillation of essential oil}

The samples were dried in the shade in natural air far from moisture and all pollutants for a fortnight in the room temperature. $100 \mathrm{~g}$ of ground rosemary were submitted to water 
distillation for $4 \mathrm{~h}$ using a Clevenger apparatus. The distilled essential oils were dried over anhydrous sodium sulphate, filtered and stored at $4{ }^{\circ} \mathrm{C}$.

\section{3. Gas chromatography}

The gas chromatographic analyzes were performed using a Hewlett Packard 6890 chromatograph equipped with a nonpolar column HP5MS (30 x $0.25 \mathrm{~mm}$ d.i. , Film thickness 0.25 microns) and a flame ionization detector. The procedures conditions were as follow: carrier gas: nitrogen, flow rate $0.8 \mathrm{ml} / \mathrm{min}$, injector temperature: $250{ }^{\circ} \mathrm{C}$, detectors temperature: $300{ }^{\circ} \mathrm{C}$, temperature program: from 60 to 250 at $2{ }^{\circ} \mathrm{C} / \mathrm{min}$, with two levels: 8 minutes at $60{ }^{\circ} \mathrm{C}$ and $15 \mathrm{~min}$ at $280{ }^{\circ} \mathrm{C}$, injection of $0.4 \mu \mathrm{l}$ of pure essential oil and $1 \mu \mathrm{l}$ of absolute mode: mode split 1: 20.

In order to determine retentions indices (RI) a series of n-alkanes (C5-C28) mixture was analysed under the same operative conditions on HP-5 columns and the sample indices were calculated following Van den Dool and Kratz [25].

\section{4. Gas chromatography and mass spectrometry (GC/MS) analysis conditions}

The essential oils were analyzed on an apparatus of gas chromatography coupled to mass spectrometry brand Hewlet Packard 5973 A, equipped with an apolar capillary column (HP5MS, $30 \mathrm{~m} \times 0.25 \mathrm{~mm}$, phase thickness: $0.25 \mu \mathrm{m}$ ). the detection mode: electronic impact, ionization current: $70 \mathrm{eV}$, carrier gas: helium, flow rate: $0.7 \mathrm{ml} / \mathrm{mn}$, the source pressure: 10-7 mbar, interface temperature: $280{ }^{\circ} \mathrm{C}$, injection: $250{ }^{\circ} \mathrm{C}$, the programming of the oven: $2{ }^{\circ} \mathrm{C} / \mathrm{min}$ from $60{ }^{\circ} \mathrm{C}$ to $280{ }^{\circ} \mathrm{C}$, with isothermal: $8 \mathrm{~min}$ at $60{ }^{\circ} \mathrm{C}$. and 15 minutes at $280^{\circ} \mathrm{C}$. 0.1 to $0.2 \mu \mathrm{l}$ of pure essential oil and $1 \mu 1$ absolutely were injected in split mode 1: 20.

The identification of the essential oil constituents was based on a comparison of their retention times to $n$-alkanes, compared to published data and spectra of authentic compounds using their mass spectra compared to the Wiley version 7.0 library [26-28]. as well as by comparison of the fragmentation patterns of mass spectra with those reported in the literature (Adams, 2007). The chromatographic conditions were identical to those used for GC analysis.

\section{5. Antioxidant activity}

The ability of M. vulgare oil to scavenge free radicals were assayed with the use of a synthetic free radical compound, 1,1-diphenyl-2-picrylhydrazyl (DPPH), according to the method employed by Bersuder [29], a volume of $500 \mu 1$ of each sample was mixed with $50 \mathrm{ml}$ of ethanol and $(0.02 \%, \mathrm{w} / \mathrm{v})$ of DPPH in $99.5 \%$ ethanol. The mixture was shaken vigorously and incubated in the dark. After $30 \mathrm{~min}$, the absorbance was measured at $517 \mathrm{~nm}$ using a spectrophotometer. The DPPH radical-scavenging activity was calculated as follows:

$$
\text { Radical-scavenging activity }=\left[\left(A_{\text {blank }}-A_{\text {sample }}\right) / A_{\text {blank }}\right] \times 100
$$

where, $A_{\text {blank }}$ and $A_{\text {sample }}$ are the absorbance of the control (blank) and the sample, respectively.

The $\mathrm{IC}_{50}$ value is defined as the amount of antioxidant necessary to inhibit DPPH radical formation by $50 \%$. The synthetic antioxidant reagent BHT was used as a positive control. The values are presented as the means of triplicate analysis. 


\section{6. Antibacterial assay dilution method}

The minimal inhibitory concentration (MIC) of essential oil was determined using the Mueller Hinton broth (MHB) dilution method [29]. All tests were performed in MHB supplemented with ethanol $5 \%$ [30]. Bacterial strains were cultured overnight in MHB at 37 ${ }^{\circ} \mathrm{C}$. Tubes of MHB containing various concentrations of oils were inoculated with $10 \mu 1$ bacterial inoculums adjusted to $106 \mathrm{CFU} / \mathrm{ml}$. They were incubated under shaking conditions $(100-120 \mathrm{rpm})$ at $37^{\circ} \mathrm{C}$ for $24 \mathrm{~h}[31,32]$. Control tubes without tested samples were essayed simultaneously. The essays were performed in triplicate. The MIC was defined as the lowest concentration preventing visible growth [33].

\section{RESULTS AND DISCUSSION}

\section{1. Chemical composition}

The peaks of GC-MS spectrum found in previous work [1]. The search analysis in the digital library. The percentages and the retention indices of the identified components are listed in table 1 in the order of their elution on the HP-5MS column. GC-MS analysis of M.vulgare essential oil led to the identification of fifty (50) compounds, accounting for 82.42 $\%$ of the total oil. The yield of essential oil obtained by hydrodistillation from aerial part of plant was $0.04 \%$, and the Table illustrates that also the nine components with a supremacy of three major compononents: 4,8,12,16-Tetramethyl heptadecan-4-olid (16.97\%), Germacrene D-4-ol $(9.61 \%), \alpha$ - pinene $(9.37 \%)$. They represnt about $36 \%$ of $56 \%$ and shows the different chemical groups with a dominance of other compounds with $41.64 \%$ of the total rate of volatil oil, followed by Oxygenated sesquiterpene with a lower rate $(13.17 \%)$ and, Monoterpene hydrocarbon (12.61\%) Oxygenated monoterpene (9.46 \%), Sesquiterpene hydrocarbon $(5.58 \%)$ respectively.

\section{2. Antioxidant activity}

Relatively stable organic radical DPPH has been widely used in the determination of the antioxidant activity of the essential oil. DPPH radical decreased in the presence of a hydrogen donor, that is, a free radical-scavenging antioxidant. In the DPPH-test, the ability of the essential oil to act as the donor of hydrogen atoms or electrons in the transformation of DPPH into its reduced form DPPH-Hwas measured spectrophotometrically. Assessed samples were able to reduce the stable violet DPPH radical to the yellow DPPH-H, reaching $50 \%$ of reduction with $\mathrm{IC} 50$ values. Lower $\mathrm{IC}_{50}$ value indicates higher antioxidant activity. The results represented in Figure 1 of the DPPH radical scavenging activities (\% inhibition) of various concentrations of $M$. vulgare oil showed a concentration dependent activity profile. As shown, it is clear that as the concentration increased, the scavenging effect also increased with inhibitory activity observed as was in the case of $M$. vulgare oil, reaching as high as 254 at $1000 \mu \mathrm{g} / \mathrm{ml}$. This value is too close to the activity potentials of synthetic antioxidants BHT $(35 \mu \mathrm{g} / \mathrm{ml})$ at the same concentration. The amount of the essential oil needed for $50 \%$ inhibition of free radical activity is expressed by $\mathrm{IC}_{50}$ (the concentration reducing $50 \%$ of $\mathrm{DPPH})$.

The lower the $\mathrm{IC}_{50}$ value is, the greater the free radical-scavenging activity. The results depicted in Figure 2 indicate that $M$. vulgare essential oil exhibited an $\mathrm{IC}_{50}$ value of 153.84 $\mu \mathrm{g} / \mathrm{ml}$, which is about 2 times higher than the synthetic antioxidant (BHT). The efficiency of an antioxidant component to reduce DPPH essentially depends on its hydrogen donating ability, which is directly related to the less content of phenolic hydroxyl moieties. 


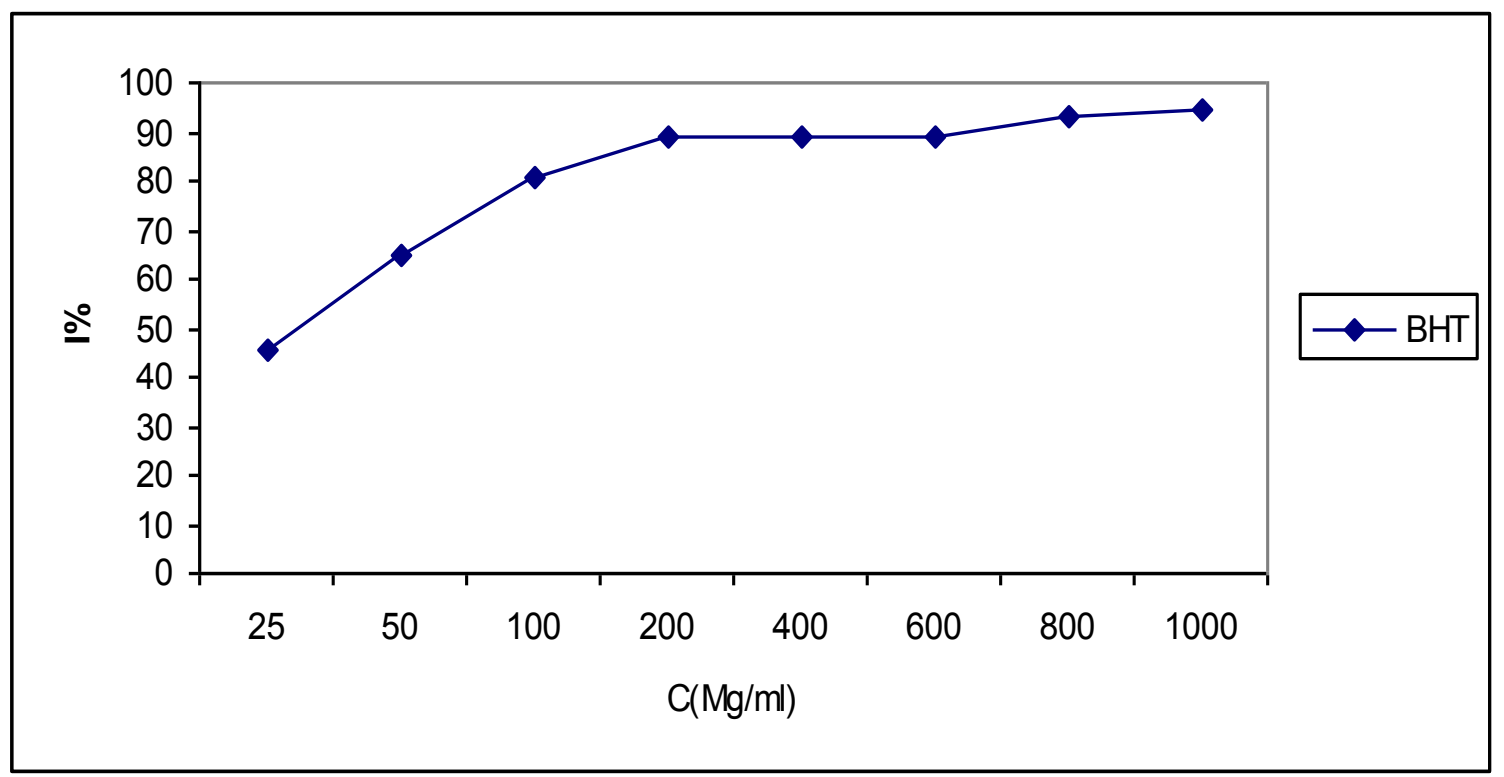

Figure 1. The synthetic antioxidant BHT.

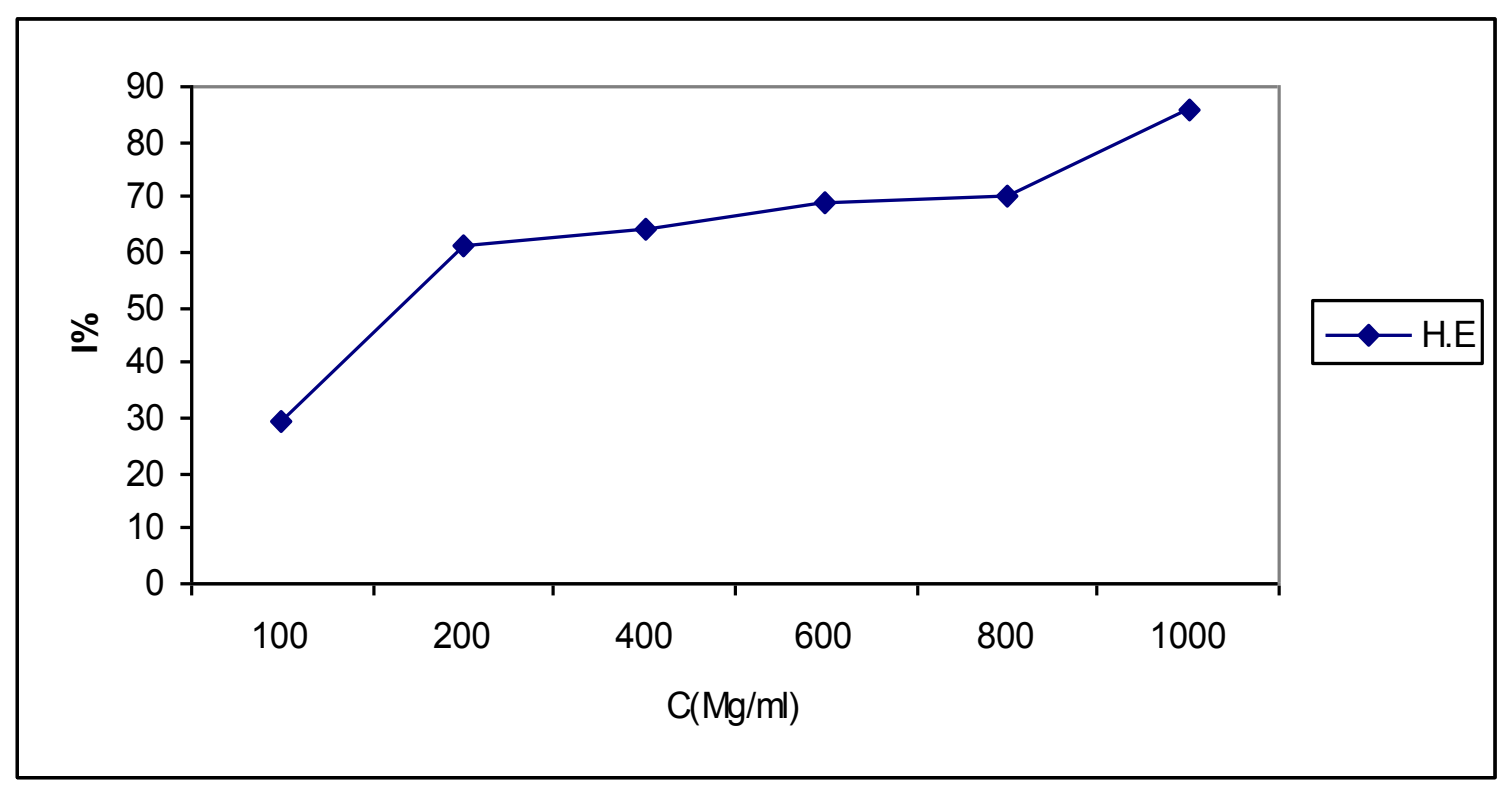

Figure 2. Antioxidant activity of $M$. vulgare essential oil.

\section{2. Antibacterial activity}

The Antibacterial activities of $M$. vulgare essential oil against microorganisms examined in the present study and their potency were qualitatively and quantitatively assessed by the presence or absence of inhibition zones and zone diameter (DD), the medium 
inhibitory concentration $\left(\mathrm{IC}_{50}\right)$ and the minimal inhibitory concentration (MIC) values. This essential oil displayed varied antibacterial activity. As can be seen from Table 2, essential oil inhibited the growth of bacterial for Gram (+) and Gram (-) bacterias, along with $\mathrm{IC}_{50}$ and MIC values ranging from $0.1-15 \mu \mathrm{l} / \mathrm{ml}$, respectively. The activities of essential oil tested against all strains (Listeria monocytogene, Pseudomonas aeruginosa, Agrobacterium tumefaciens and Salmonella enterica) has been revealed.

Table 2. Minimal inhibitory concentration (MIC) of essential oil from M. vulgare.

\begin{tabular}{|c|c|c|c|c|c|c|c|c|c|c|c|c|c|}
\hline The concentrations $(\mu \mathrm{l} / \mathrm{ml})$ & 0.1 & 0.2 & 0.3 & 0.4 & 0.5 & 1 & 2 & 3 & 4 & 5 & 10 & 15 & Ref \\
\hline \multicolumn{13}{|c|}{ Bacterias of Gram +} & \\
\hline Bacillus subtilis (ATCC6663) & + & + & + & + & + & + & + & + & + & + & + & - & {$[1]$} \\
\hline Micrococcus luteus (AТCC9314) & + & + & + & + & + & + & + & + & + & + & - & - & {$[1]$} \\
\hline Listeria monocytogene (CIP82110) & + & + & + & + & + & + & + & + & + & + & - & - & $\begin{array}{c}\text { In } \\
\text { this } \\
\text { work }\end{array}$ \\
\hline \multicolumn{13}{|c|}{ Bacterias of Gram - } & \\
\hline Escherichia Coli (CIP54.8) & + & + & + & + & + & + & + & + & + & + & - & - & {$[1]$} \\
\hline Klebsiella pneumoniae (CIP82.91) & + & + & + & + & + & + & + & + & + & + & + & - & {$[1]$} \\
\hline Pseudomonas aeruginosa (CIPA22). & + & + & + & + & + & + & + & + & + & + & + & - & $\begin{array}{c}\text { In } \\
\text { this } \\
\text { work }\end{array}$ \\
\hline Agrobacterium tumefaciens $\left(N^{\circ} 2410\right)$ & + & + & + & + & + & + & + & + & + & + & + & - & $\begin{array}{c}\text { In } \\
\text { this } \\
\text { work }\end{array}$ \\
\hline Salmonella enterica (CIP 81.3) & + & + & + & + & + & + & + & + & + & + & + & - & $\begin{array}{c}\text { In } \\
\text { this } \\
\text { work } \\
\end{array}$ \\
\hline
\end{tabular}

\section{CONCLUSION}

The essential oil of M. vulgare showed significant antimicrobial activity. Analysis by GC-MS and GC/FID of M. vulgare essential oil of eastern Algeria and tested represent an inexpensive source of natural antibacterial substances for use in pathogenic systems to prevent the growth of bacteria and extend the shelf life of the processed food.

\section{ACKNOWLEDGMENTS}

The authors gratefully acknowledge Mr SALAH NEGHMOUCHE Maitre assistant at The University of El Oued, Mrs Aicha Hassani professor at The University of ENS Kouba Algiers for his 
help and advice, and the Technical staff in the Laboratory of Molécules Bio-active et Valorisation de la Biomasse, École Normale Supérieure, Kouba-Algiers for its support.

\section{References}

[1] A. Abadi, A. Hassani, International Letters of Chemistry, Physics and Astronomy 9(1) (2013) 17-24.

[2] Nagy M., Svajdlenka E., J. Essent. Oil Res. 10 (1998) 585-587.

[3] Saleh M. M., Glombitza K. W., Planta Med 55 (1989) 105-108.

[4] Morteza-Semnani K., Saeedi M., J. Essent. Oil Bearing Plants 7 (2004) 239-242.

[5] Asadipour A., Mehrabani M., Nazeri V., Tabarraii M., Ulum-i-Daroei 2 (2005) 77-82.

[6] Khanavi M., Ghasemian L., Hosseiny Motlagh E., Hadjiakhoondi A., Shafiee A., Flav. Fragr. J. 20 (2005) 324-326.

[7] Sasaki Y. F., Kawaguchi S., Kamaya A., Ohshita M., Kabasawa K., Iwama K., Taniguchi K., Tsuda S., Mutat. Res. 519 (2002) 103-109.

[8] Djeridane A., Yousfi M., Nadjemi B., Boutassouna D., Stocker P., Vidal N., Food Chem. 97 (2006) 654-660.

[9] Singer A. C., Crowley D., Thompson I. P., Trends Biotechnol. 21 (2003) 123-130.

[10] Lapornik B., Prosek M., Wondra A. G., J. Food Eng. 71 (2005) 214-222.

[11] Burt S., Int. J. Food Microbiol. 94 (2004) 223-253.

[12] Roman R. R., Aharcon A. F., Lara L. A., Flores S. J. L., Arch Med Res. 23(1) (1992) 59-64.

[13] El-Bardai S., Morel N., Wibo M., Fabre N., Llabres G., Lyoussi B., Quetin L., Plant Med 69(1) (2003) 75-77.

[14] El-Bardai S., Lyoussi B., Wibo M., Morel N., Clin Exp Hyprtens 26(6) (2004) 465-474.

[15] DeSouza M. M., DeJesus R. A. P., Cechinel-Filho V., Schlemper V., Phytomed 5(2) (1998) 103-107.

[16] Sahpaz S., Garbacki N., Tits M., Bailleul F., J. Ethnopharmacol 79(3) (2002) 389-392.

[17] Schlemper V., Ribas A., Nicolau M., Cechinel-Filho V., Phytomedicine 3 (1993) 211-216.

[18] Kadri A., Zarai Z., Bekir A., Gharsallah N., Damak M., Gdoura R., African Journal of Biotechnolgy 10(198) (2011) 3908-3914.

[19] Stulzer H. K., Tagliari M. P., Zampirolo J. A., Cechinel-Filho V., Schlemper V., J. Ethnopharmacol 108(3) (2006) 379-392.

[20] Baratta M. T., Dorman H. J. D., Deans S. G., Figueiredo A. C., Barroso J. G., Ruberto G.,. Flav. Fragr. J. 13 (1998) 235-44.

[21] Bounatirou S., Smiti S., Miguel M. G., Faleiro L., Rejeb M. N., Neffati M., Costa M. M., Figueiredo A. C., Barroso J. G., Pedro L. G., Food Chem. 2007, 105 (2007) 146-155. 
[22] Fabio A., Cermelli C., Fabio G., Nicoletti P., Quaglio P., Phytother Res. 21 (2007) 374-377.

[23] Voravuthikunchai S. P., Sririrak T., Limsuwan S., Supawita T., Iida T., Honda T., J. Health Sci. 51(5) (2005) 590-596.

[24] Burt S., International Journal of Food Microbiology 94 (2004) 223-253.

[25] H. Van den Dool, P. D. Kratz, J. Chromatogr. 11 (1963) 463.

[33] F. Macchioni, P. L. Cioni, G. Flamini, I. Morelli, S. Maccioni, M. Ansaldi, Flavour Frag. J. 18 (2003) 139.

[26] V. Roussis, P. Katerina, V. Constantinos, P. V. Catherine, O. Antonio, J. Essent. Oil Res. 13 (2001) 118.

[27] R. P. Adams, Identification of Essential Oils by Ion Trap Mass Spetroscopy, Allured Publishing Corporation, Carol Stream, IL, USA, 1995.

[28] May J., Chan C. H., King A., Williams L., French G. L., J. Antimicrobial Chemoter 45 (2000) 639-643.

[29] Ferreira A., Proenca A. C., Serralheiro C. M. L. M., Araujo M. E. M., J. Ethnopharmacology 2006, 108 (2006) 31-37.

[30] Saidana D., Mahjoub M. A., Boussaada O., Chriaa J., Cheraif I., Daami-Remadi M., Mighri Z., Helal A. N.,Microbiology Res. 2 008, 163 (2008) 445-455.

[31] Boussaada O., Ammar S., Saidana D., Chriaa J., Chraif I., Daami-Remadi M., Helal A. N., Mighri Z., Microbiology Res. 163 (2008) 87-95.

[32] Hammer K. A., Carson C. F., Riley T. V., J. App. Microbiology 86 (1999) 985-990.

[33] Delaquis P. J., Stanich K., Girard B., Mazza G., Int. J. Food Microbiology 74 (2002) 101-109. 